\title{
PERBANDINGAN EFEKTIFITAS TRAMADOL 1,5 MG/KGBB IV DENGAN KETOROLAK 30 MG IV TERHADAP TINGKAT NYERI PASCA OPERASI SEKSIO SESAREA
}

\author{
${ }^{1}$ Aldy Yosieto \\ ${ }^{2}$ Lucky Kumaat \\ ${ }^{2}$ Iddo Posangi \\ ${ }^{1}$ Kandidat Skripsi Fakultas Kedokteran Universitas Sam Ratulangi Manado \\ ${ }^{2}$ Bagian Anestesiologi dan Terapi Intensif Fakultas Kedokteran \\ Universitas Sam Ratulangi Manado \\ Email: ayosieto11_090@yahoo.com
}

\begin{abstract}
Surgery lead to pain manifestation that could occur after surgery (post-operative pain). The purpose of this study is to compare the analgesic efficacy of tramadol with ketorolac for preventing post-operative pain in caesarean section patients. This study was performed on 26 female patients, aged 17-64 years old, American Society of Anesthesiologist (ASA) physical state I-II, had 18,5-29,9 Body Mass Index (BMI), who underwent caesarean section surgery in Prof. R. D. Kandou Manado General Hospital from December 2014 to January 2015. The subjects was divided into two groups, who would receive either 1,5 $\mathrm{mg} / \mathrm{BW}$ intravenous tramadol (drips) or $30 \mathrm{mg}$ intravenous ketorolac, 1,5 hours after the anesthesia induction. Systolic and diastolic blood pressure, heart rate, respiration rate, and Visual Analogue Scale (VAS) score were taken for 8 hours with 2 hours interval $\left(0,2^{\text {nd }}, 4^{\text {th }}\right.$, $6^{\text {th }}, 8^{\text {th }}$ hours). The statistical analysis was done using T-test and Mann-Whitney test.

Conclusion: The result is the systolic and diastolic blood pressure, heart rate, respiration rate, and VAS score between the two groups have no significant differences $(p>0,05)$. Therefore, $1,5 \mathrm{mg} / \mathrm{BW}$ intravenous tramadol and $30 \mathrm{mg}$ intravenous ketorolac have same analgesic efficacy in preventing post-operative pain in caesarean section patients.
\end{abstract}

Keywords: tramadol, ketorolac, post-operative pain, caesarean section

\begin{abstract}
Abstrak: Pembedahan dapat menyebabkan timbulnya rasa nyeri yang bisa muncul setelah pembedahan (nyeri pasca operasi). Tujuan penelitian ini adalah untuk mengetahui perbandingan efektifitas tramadol dengan ketorolak terhadap tingkat nyeri pasca operasi seksio sesarea. Penelitian dilakukan pada 26 pasien wanita (17-64 tahun), status fisik American Society of Anesthesiologist (ASA) I-II, dengan Indeks Massa Tubuh (IMT) 18,529,9 yang menjalani bedah seksio sesarea di Rumah Sakit Prof. R. D. Kandou Manado di bulan Desember 2014 - Januari 2015. Pasien dibagi menjadi dua kelompok yaitu yang menerima tramadol $1,5 \mathrm{mg} / \mathrm{kgBB}$ secara intravena (IV) lewat tetesan infus (drips) atau ketorolak $30 \mathrm{mg}$ IV, 1,5 jam setelah induksi anestesia dilakukan. Data yang diambil adalah nilai tekanan darah sistolik dan diastolik, nadi per menit, respirasi per menit, dan skor Visual Analogue Scale (VAS) setiap 2 jam setelah tramadol atau ketorolak diberikan (jam ke 0, 2, 4, 6, 8). Analisis statistik dilakukan dengan menggunakan uji-t dan uji Mann-Whitney.

Simpulan: Ditemukan bahwa nilai tekanan darah sistolik, diastolik, nadi, respirasi, dan skor VAS dari kedua kelompok penelitian tidak memberikan perbedaan yang bermakna $(p>0,05)$. Simpulan penelitian adalah tramadol $1,5 \mathrm{mg} / \mathrm{kgBB}$ IV memberikan efek yang sama dengan ketorolak $30 \mathrm{mg}$ IV terhadap nyeri pasca operasi seksio sesarea.
\end{abstract}

Kata kunci: tramadol, ketorolak, nyeri pasca operasi, seksio sesarea 
Dalam ilmu anestesi dikenal istilah Trias Anestesi yang merujuk pada konsep anestesi yang terdiri atas tiga komponen yaitu narkosis (hilang kesadaran), relaksasi (hilang respon motorik), dan analgesia (hilang respon sensorik - nyeri). ${ }^{3}$ Dari antara ketiga aspek ini, analgesia memegang peranan penting karena dalam setiap pembedahan pasti memerlukan upaya penghilangan nyeri. Dan hal tersebut dapat dilakukan dengan menghambat atau merubah aliran rangsang nyeri dengan cara fisik, psikologik, fisiologik, ataupun dengan obat-obatan., ${ }^{2,4}$

Menurut International Association for Study of Pain (IASP), nyeri adalah pengalaman perasaan emosional yang tidak menyenangkan akibat terjadinya kerusakan aktual maupun potensial, atau menggambarkan kondisi terjadinya kerusakan jaringan tubuh. ${ }^{5}$ Sinyal listrik yang menghantarkan impuls nyeri berasal dari saraf perifer,dimana tempat kerusakan jaringan melepas berbagai substansi kimia yang merangsang ujung saraf, dan efeknya diperkuat oleh prostaglandin. Impuls ini kemudian dihantarkan menuju reseptor nyeri di sistem saraf pusat sampai di korteks frontalis dimana impuls tadi ditafsirkan sebagai nyeri. ${ }^{2}$ Pada pembedahan, sensasi nyeri ini juga bisa timbul setelah operasi. ${ }^{6}$

Salah satu jenis operasi yang kini sering dilakukan adalah seksio sesarea, yaitu tindakan bedah berupa pengangkatan janin (fetus) dengan menginsisi dinding abdominal dan uterus. ${ }^{7}$ Luka yang dibuat pada tindakan bedah ini pun bisa memberikan efek nyeri setelah operasi selesai.

Penanganan nyeri pasca operasi merupakan suatu komponen yang esensial dalam menangangi pasien pembedahan. Penanganan yang buruk akan meningkatkan angka morbiditas atau mortalitas pasca operasi. Terdapat banyak cara yang bisa dilakukan dalam manajemen nyeri pasca operasi, di antaranya berupa pemberian analgesia opioid atau nonopioid. $^{7}$

Telah banyak dilakukan penelitian tentang analgesia opioid yang aman, efektif, dan non-adiktif. Ditemukan bahwa morfin tetap menjadi pilihan analgesia opioid yang terbaik. ${ }^{9,10}$ Selain morfin, tramadol juga biasa digunakan sebagai analgesia opioid pada tindakan bedah. ${ }^{10-14}$ Hadi (2004) menyimpulkan bahwa pemberian pasca operasi tramadol sama efektifnya dengan morfin dalam manajemen nyeri pasca operasi. ${ }^{11}$ Dalam penelitian yang lain, ditemukan bahwa tramadol tidak memberikan efek samping yang biasa muncul pada pemberian morfin berupa terjadinya miosis, dan perubahan perilaku. ${ }^{12}$ Tramadol juga memiliki efek depresi napas yang lebih rendah dibandingkan morfin. ${ }^{13}$

Dalam banyak penelitian, ditemukan bahwa analgesia opioid sepert morfin memberi banyak efek samping. Oleh karena itu, penggunaan analgesia lain seperti analgesia non-opioid pun sering digunakan. ${ }^{15-18}$ Ketorolak adalah salah satu obat anti inflamasi non-steroid (OAINS) yang merupakan analgesia non-opioid dan cukup poten. $^{19,20,21}$ Seperti OAINS pada umumnya, ketorolak menghambat sintesis prostaglandin yang berperan dalam transmisi nyeri. Ketorolak juga memiliki efektifitas yang lebih baik dari morfin, petidin (meperidin) dan pentazocine dalam menangani nyeri pasca operasi sedang sampai berat, dengan efek samping yang lebih sedikit. ${ }^{21}$

Beberapa penelitian telah dilakukan untuk membandingkan efektifitas tramadol dan ketorolak dalam penanganan nyeri karena tindakan bedah. ${ }^{22-25}$ Walau tidak memberi perbedaan yang signifikan, tingkat nyeri pasca bedah pada pasien yang diberi tramadol $100 \mathrm{mg}$ intravena (IV) lebih rendah dari yang diberi ketorolak 30 mg IV. ${ }^{22}$ Lalu di tahun 2002, Putland menemukan bahwa pemberian premedikasi tramadol $\quad 1,5 \quad \mathrm{mg} / \mathrm{kgBB} \quad$ IV 
pada pasien yang menjalani laparoskopi sterilisasi mempunyai pengaruh yang lebih bermakna terhadap tingkat nyeri pasca operasi yang lebih rendah daripada yang diberi ketorolak $10 \mathrm{mg} \mathrm{IV}^{23}$ Pemberian pasca operasi tramadol $30 \mathrm{mg}$ IV ditambah dosis pemeliharaan sebanyak $15 \mathrm{mg} / \mathrm{jam}$ juga lebih baik dari ketorolak $10 \mathrm{mg}$ IV ditambah dosis pemeliharaan sebanyak 5 $\mathrm{mg} / \mathrm{jam}$ dalam menurunkan tingkat nyeri pasca operasi. ${ }^{24}$ Tapi, hal berbeda ditunjukkan oleh penelitian Ong dimana premedikasi ketorolak $30 \mathrm{mg}$ IV memberi efek penurunan tingkat nyeri pasca operasi lebih baik daripada premedikasi tramadol $50 \mathrm{mg}^{25}$

Penelitian-penelitian

tentang perbandingan efektifitas tramadol dengan ketorolak di atas telah menggunakan berbagai variasi dosis dalam pelaksanaannya. Walaupun begitu, sejauh ini penulis belum menemukan ada yang membandingkan efektifitas pemberian pasca operasi tramadol $1,5 \mathrm{mg} / \mathrm{kgBB} \mathrm{IV}$ dan ketorolak $30 \mathrm{mg}$ IV terhadap tingkat nyeri pasca operasi. Berdasarkan permasalahan tersebut maka penulis melaksanakan penelitian ini.

\section{METODE PENELITIAN}

Penelitian ini merupakan penelitian observasional anlitik berupa studi crosssectional prospektif. Jumlah subjek yang terkumpul adalah 26 orang, yaitu pasien bedah seksio sesarea yang memenuhi kriteria inklusi dan eksklusi. Kriteria inklusinya yaitu wanita berusia antara 1764 tahun, status fisik ASA I-II, tidak obesitas (IMT 18,5-29,9), dan menggunakan bupivakain $0,5 \%$ sebagai anestesi spinal berupa injeksi subarachnoid. Sedangkan kriteria eksklusinya berupa pasien yang termasuk dalam kontraindikasi penggunaan bupivakain, tramadol, dan ketorolak, atau pasien yang menolak bersedia menjadi subjek penelitian.

Setelah mendapatkan persetujuan etik penelitian dari Unit Penelitian Kesehatan Terpadu (UPKT) RSUP Prof. R. D.
Kandou Manado, maka penelitian dimulai. Dilakukan penjelasan mengenai penelitian yang akan dilakukan kepada subjek dengan menandatangai persetujuan (informed consent). Subjek yang setuju lalu dikelompokkan ke dalam 2 kelompok perlakuan, yaitu kelompok $\mathrm{T}$ atau kelompok K. Randomisasi dilakukan dengan menggunakan metode consecutive sampling dimana subjek yang datang dimasukkan secara berurutan dan bergantian ke dalam kelompok perlakuan hingga waktu penelitian selesai.

Pada kedua kelompok dilakukan perlakuan standar untuk tindakan pembedahan seksio sesarea di RSUP Prof. R. D. Kandou Manado. Pemasangan alat monitor tanda vital dilakukan ketika subjek memasuki ruang operasi, kemudian data tanda vital berupa tekanan darah, laju nadi, dan respirasi dicatat. Setelah dilakukan tindakan aseptik dan antiseptik pada punggung subjek, dilakukan induksi anestesia dengan menggunakan bupivakain 0,5\% $20 \mathrm{~mL}$ yang diinjeksikan ke dalam ruang subarachnoid pada medula spinalis. Setelah itu, pembedahan dimulai.

Satu setengah jam setelah induksi anestesia dilakukan, diberikan analgesia berupa tramadol atau ketorolak. Kelompok $\mathrm{T}$ menerima tramadol $1,5 \mathrm{mg} / \mathrm{kgBB} \mathrm{IV}$ (drips) yang diencerkan pada larutan Ringer Laktat $500 \mathrm{~mL}$ dan kelompok $\mathrm{K}$ menerima ketorolak $30 \mathrm{mg}$ IV yang diinjeksikan lewat saluran infus. Tanda vital berupa tekanan darah, laju nadi, dan respirasi dicatat. Lalu, ditanyakan tentang seberapa sakit nyeri yang dirasakan subjek dengan menggunakan skor VAS, yang berkisar antara nilai 0 (tidak nyeri sama sekali) hingga 10 (nyeri maksimal yang tak tertahankan). Pengukuran tekanan darah, laju nadi, respirasi, dan skor VAS dilakukan setiap 2 jam setelah itu selama 8 jam.

\section{HASIL PENELITIAN}

Telah dilakukan penelitian untuk menilai pengaruh pemberian tramadol 1,5 
$\mathrm{mg} / \mathrm{kgBB} \quad \mathrm{IV}$ dibandingkan dengan ketorolak $30 \mathrm{mg}$ IV terhadap tingkat nyeri pasca operasi seksio sesarea. Penelitian dilakukan pada total 26 subjek yang dibagi dalam 2 kelompok, yaitu kelompok yang mendapat analgesia pasca operasi berupa tramadol 1,5 mg/kgBB IV (kelompok T) sebanyak 13 subjek dan kelompok yang mendapat analgesia pasca operasi berupa ketorolak 30 mg IV (kelompok K) sebanyak 13 subjek. Karakteristik subjek yang menjalani penelitian dapat dilihat pada Tabel 1. Setelah dibandingkan, karakteristik subjek kelompok $\mathrm{T}$ dan $\mathrm{K}$ tidak memberikan pengaruh yang bermakna (nilai $\mathrm{p}>0,05$ ).

Tabel 1. Karakteristik Subjek Penelitian

\begin{tabular}{lccl}
\hline Karakteristik & $\begin{array}{c}\text { Tramadol } \\
\text { rata-rata } \\
{[\text { [Sd] }}\end{array}$ & $\begin{array}{c}\text { Ketorolak } \\
\text { rata-rata } \\
{[\text { [Sd] }}\end{array}$ & Nilai p \\
\hline Usia (tahun) & $27,8[7,84]$ & $29,1[5,23]$ & 0,622 \\
Berat badan (kg) & $58,8[4,59]$ & $60,46[3,25]$ & 0,289 \\
Tinggi badan (cm) & $151,4[5,36]$ & $153[5,49]$ & 0,477 \\
IMT (kg/m $\left.{ }^{2}\right)$ & $25,7[2,31]$ & $25,9[2,04]$ & 0,793 \\
TDS awal (mmHg) & $122,3[13,01]$ & $129,2[13,82]$ & 0,179 \\
TDD awal (mmHg) & $75,4[8,77]$ & $82,3[6]$ & 0,054 \\
Respirasi awal (kali/menit) & $22,31[3,9]$ & $21,7[3,38]$ & 0,854 \\
\hline
\end{tabular}

Keterangan : Nilai p dihitung berdasarkan uji-T, kecuali untuk Tekanan Darah Sistol (TDS) awal, Tekanan Darah Diastol (TDD) awal, dan respirasi awal menggunakan uji Mann-Whitney karena memiliki data yang tidak terdistribusi normal. Sd: simpangan baku

Tekanan darah sistolik (TDS) rata-rata ketika diberikan analgesia (tramadol/ketorolak) pada kelompok $\mathrm{T}$ adalah sebesar $117,7( \pm 8,32)$ dan pada kelompok K sebesar $120( \pm 9,61)$ dengan perbedaan tidak bermakna menurut statistika $(\mathrm{p}>0,05)$. Hal yang serupa diperoleh pada jam-jam selanjutnya yaitu 2 , 4, 6, dan 8 jam setelah analgesia diberikan. Perbedaan tekanan darah sistolik terbesar terjadi pada jam ke-8, dimana TDS ratarata kelompok $\mathrm{T}$ sebesar $121,5( \pm 8,99)$ dan
TDS rata-rata kelompok K sebesar 127,9 $( \pm 6,99)$. Meskipun demikian, nilai p-nya $(0,077)$ masih belum memberikan perbedaan yang bermakna juga. (Tabel 2)

Jika dilihat dari perbandingan Tekanan Darah Diastolik (TDD), kelompok K memiliki kisaran rata-rata lebih tinggi daripada kelompok T. Hal ini bisa dilihat pada jam ke-0 (T0) sampai jam ke-8 (T8) (Tabel 3). Tapi, perbedaan ini tidak memberikan pengaruh yang bermakna. 
Jurnal e-Clinic (eCl), Volume 3, Nomor 1, Januari-April 2015

Tabel 2. Perbandingan Rata-rata Tekanan Darah Sistolik pada 2 Kelompok Perlakuan Setiap 2 Jam

\begin{tabular}{cccc}
\hline Waktu & $\begin{array}{c}\text { Tramadol } \\
\text { rata-rata } \\
{[\text { Sd] }}\end{array}$ & $\begin{array}{c}\text { Ketorolak } \\
\text { rata-rata } \\
{[\text { [Sd] }}\end{array}$ & Nilai p \\
\hline T0 & $117,7[8,32]$ & $119,2[9,54]$ & 0,622 \\
T2 & $120[8,17]$ & $122,3[11,66]$ & 0,622 \\
T4 & $120,8[8,62]$ & $123,9[9,61]$ & 0,483 \\
T6 & $123,1[10,31]$ & $126,9[6,3]$ & 0,343 \\
T8 & $121,5[8,99]$ & $127,7[7,25]$ & 0,101 \\
\hline
\end{tabular}

Keterangan : Nilai p dihitung berdasarkan uji Mann-Whitney karena kelompok data ini memiliki data yang tidak terdistribusi normal. Bermakna bila $\mathrm{p}<0,05$

Tabel 3. Perbandingan Rata-rata Tekanan Darah Diastolik pada 2 Kelompok Perlakuan Setiap 2 Jam

\begin{tabular}{cccc}
\hline Waktu & $\begin{array}{c}\text { Tramadol } \\
\text { rata-rata } \\
{[\text { Sd] }}\end{array}$ & $\begin{array}{c}\text { Ketorolak } \\
\text { rata-rata } \\
{[\text { Sd] }}\end{array}$ & Nilai p \\
\hline T0 & $71,5[8,9]$ & $73,9[11,21]$ & 0,567 \\
T2 & $71,5[9,87]$ & $75,4[7,76]$ & 0,269 \\
T4 & $74,6[8,77]$ & $78,4[7,89]$ & 0,277 \\
T6 & $76,9[7,51]$ & $79,2[6,41]$ & 0,479 \\
T8 & $76,9[9,47]$ & $81,5[3,76]$ & 0,166 \\
\hline
\end{tabular}

Keterangan : Nilai p dihitung berdasarkan uji Mann-Whitney karena kelompok data ini memiliki data yang tidak terdistribusi normal. Bermakna bila $\mathrm{p}<0,05$
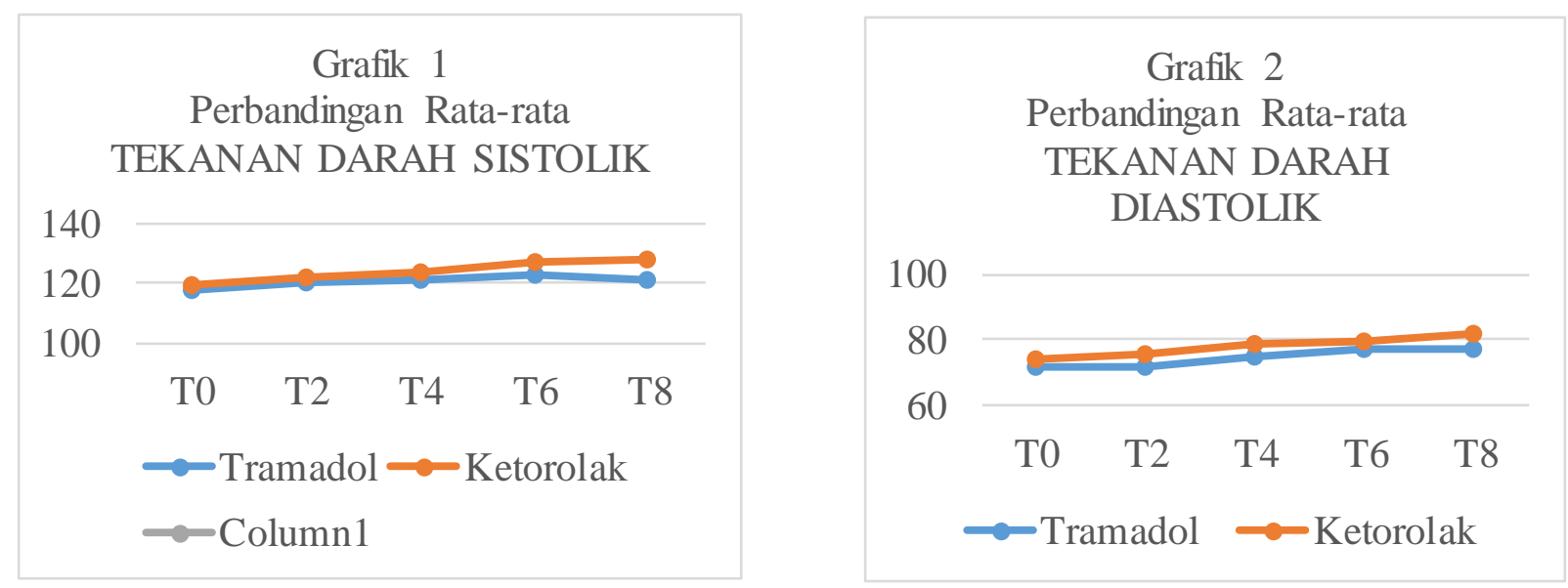
Pada jam ke-0 (T0) pemberian analgesia hingga jamnya yang ke-8 (T8), tampak adanya peningkatan denyut nadi per menit secara berkala di subjek kelompok $\mathrm{K}$ dan subjek kelompok T. Jika dibandingkan, denyut nadi per menit dari kelompok $\mathrm{K}$ lebih besar tapi tidak memberikan perbedaan yang bermakna secara statistik. (Tabel 4).

Nilai respirasi rata-rata per menit dari subjek kelompok $\mathrm{T}$ pada saat diberi analgesia (T0) lebih rendah dari kelompok $\mathrm{K}$, dan posisi ini bertahan pada 2 jam selanjutnya (T2). Pada jam ke-4 (T4) sampai jam ke-8 (T8) justru berbalik, dimana nilai respirasi kelompok $\mathrm{T}$ menjadi lebih besar. Namun, perbedaan ini belum bisa dikatakan bermakna menurut uji statistika (Tabel 5).

Tabel 4. Perbandingan Rata-rata Denyut Nadi per Menit pada 2 Kelompok Perlakuan Setiap 2 Jam

\begin{tabular}{cccc}
\hline Waktu & $\begin{array}{c}\text { Tramadol } \\
\text { Rata-rata } \\
\text { [Sd] }\end{array}$ & $\begin{array}{c}\text { Ketorolak } \\
\text { Rata-rata } \\
\text { [Sd] }\end{array}$ & Nilai p \\
\hline T0 & $79,1[12,38]$ & $82,2[12,81]$ & 0,625 \\
T2 & $81,6[10,03]$ & $84,9[8,79]$ & 0,245 \\
T4 & $83,8[8,66]$ & $85,9[7,85]$ & 0,680 \\
T6 & $84,8[8,41]$ & $86,1[8,39]$ & 0,979 \\
T8 & $85,2[7,77]$ & $87,1[7,42]$ & 0,776 \\
\hline
\end{tabular}

Keterangan : Nilai p dihitung berdasarkan uji Mann-Whitney karena kelompok data ini memiliki data yang tidak terdistribusi normal. Bermakna bila $\mathrm{p}<0,05$
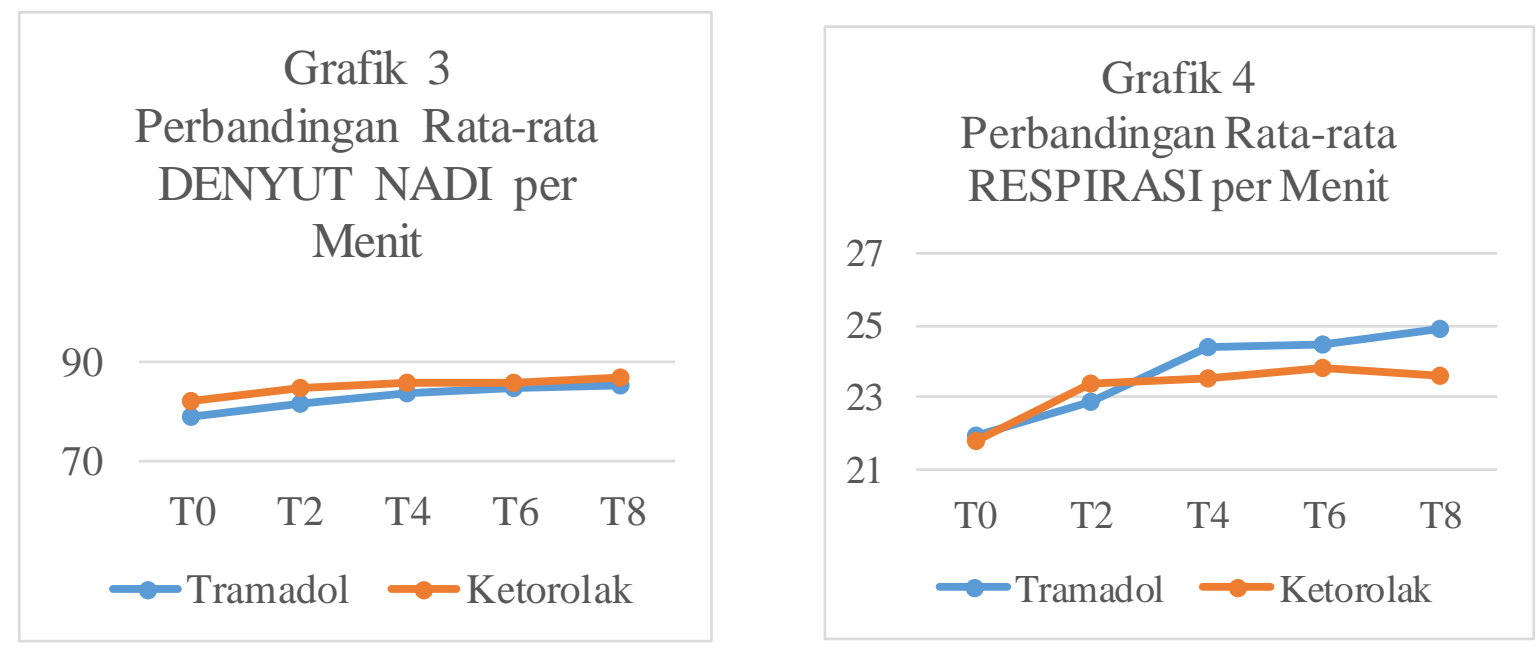
Jurnal e-Clinic (eCl), Volume 3, Nomor 1, Januari-April 2015

Tabel 5. Perbandingan Rata-rata Nilai Respirasi per Menit pada 2 Kelompok Perlakuan Setiap 2 Jam

\begin{tabular}{cccc}
\hline Waktu & $\begin{array}{c}\text { Tramadol } \\
\text { rata-rata } \\
{[\text { Sd] }}\end{array}$ & $\begin{array}{c}\text { Ketorolak } \\
\text { rata-rata } \\
{[\text { [Sd] }}\end{array}$ & Nilai p \\
\hline T0 & $21,9[3,69]$ & $21,8[2,13]$ & 0,816 \\
T2 & $22,9[3,32]$ & $23,4[1,85]$ & 0,603 \\
T4 & $24,4[3,84]$ & $23,5[1,81]$ & 0,854 \\
T6 & $24,5[4,08]$ & $23,8[1,88]$ & 0,696 \\
T8 & $24,9[3,22]$ & $23,6[2,22]$ & 0,393 \\
\hline
\end{tabular}

Keterangan : Nilai p dihitung berdasarkan uji Mann-Whitney karena kelompok data ini memiliki data yang tidak terdistribusi normal. Bermakna bila $\mathrm{p}<0,05$

Penilaian tingkat nyeri pasca operasi pada penelitian ini dinilai dengan menggunakan Visual Analogue Scale (VAS) dengan kisaran angka dari 0-10 dimana 0 berarti tak dirasakannya nyeri sama sekali dan 10 bila terasa nyeri maksimal yang tak tertahankan. Berdasarkan hasil penilaian, ditemukan bahwa terdapat peningkatan skor VAS seiring berjalannya waktu dari saat analgesia diberikan (T0) hingga jam ke-8 (T8). Pada T0, skor VAS kedua kelompok adalah 0 . Setelah dilakukan uji statistika, diketahui nilai skor VAS kedua kelompok ditemukan berbeda tidak bermakna pada tiap waktu penilaian (Tabel 6).

Tabel 6. Perbandingan Rata-rata Nilai Visual Analogue Scale (VAS) pada 2 Kelompok Perlakuan Setiap 2 Jam

\begin{tabular}{cccc}
\hline Waktu & $\begin{array}{c}\text { Tramadol } \\
\text { rata-rata } \\
\text { [Sd] }\end{array}$ & $\begin{array}{c}\text { Ketorolak } \\
\text { rata-rata } \\
\text { [Sd] }\end{array}$ & Nilai p \\
\hline T0 & $0,0[0]$ & $0,0[0]$ & 1 \\
T2 & $2,9[0,86]$ & $3[1,33]$ & 0,784 \\
T4 & $5,2[1,36]$ & $4,5[1,65]$ & 0,149 \\
T6 & $6,5[1,12]$ & $6[1,17]$ & 0,136 \\
T8 & $7,1[0,68]$ & $6,5[1,09]$ & 0,096 \\
\hline
\end{tabular}

Keterangan : Nilai p dihitung berdasarkan uji Mann-Whitney karena kelompok data ini memiliki data yang tidak terdistribusi normal. Bermakna bila $\mathrm{p}<0,05$ 
Yosieto, Kumaat, Posangi: Perbandingan efektifitas tramadol...

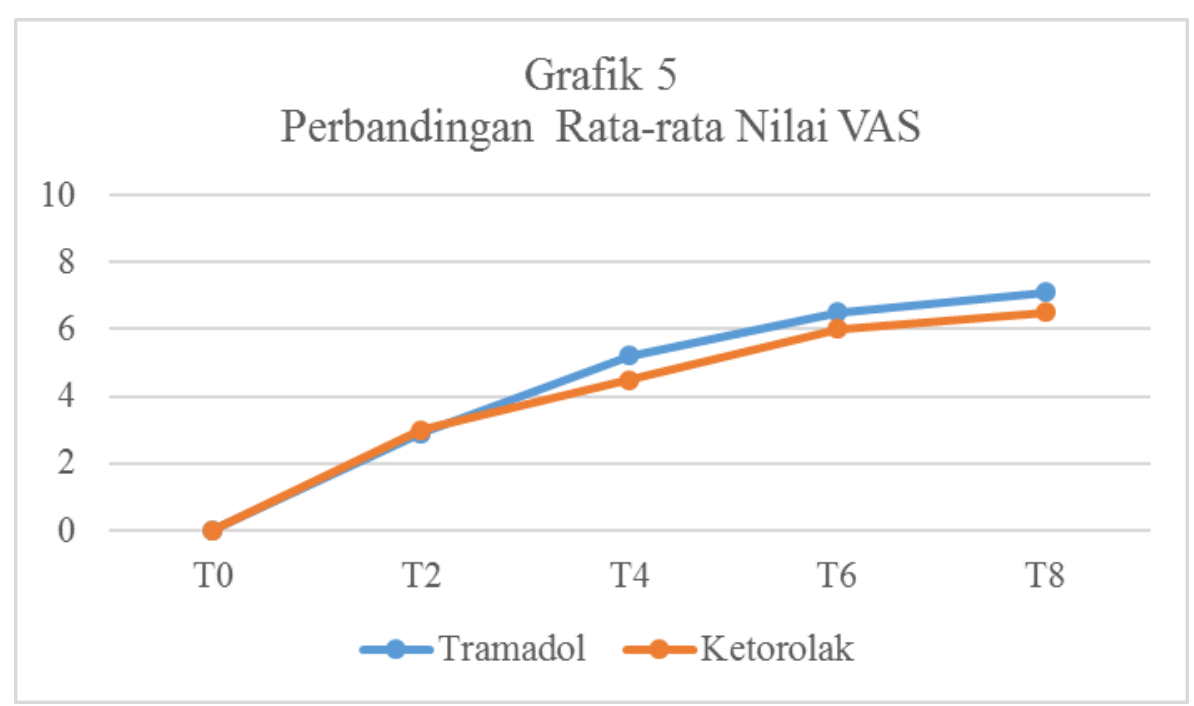

\section{BAHASAN}

Data karakteristik subjek penelitian pada Tabel 1 antara 2 kelompok perlakuan, yaitu kelompok tramadol (T) dan kelompok ketorolak (K) tidak menunjukkan perbedaan yang bermakna dari segi usia, berat badan, tinggi badan, IMT, tekanan darah sistolik, tekanan darah diastolik, dan nilai respirasi sebelum anestesia. Hal ini menjelaskan bahwa keadaan homogenitas data daripada subjek penelitian tercapai dan data yang ada layak untuk diperbandingkan secara statistika.

Kejadian nyeri pasca operasi terjadi akibat terjadinya hipersensitisasi serabut saraf perifer pada lokasi pembedahan sebelumnya. Kerusakan yang ditimbulkan di daerah tersebut memberi beban kerja yang besar pada reseptor nyeri di sekitarnya. Substansi-substansi kimia yang dilepas oleh sel ketika mengalami trauma seperti globulin, asam arakhidonat, histamine dan lainnya turut berperan dalam proses hipersensitisasi ini. Akibatnya, walaupun sudah tak ada lagi rangsangan nyeri, pasien tetap merasakan nyeri karena serabut saraf yang telah sensitive itu menginterpretasi semua rangsangan sebagain nyeri. $^{26,27}$

Dilihat dari perubahan tekanan darah sistolik dan diastolik setelah analgesia diberikan, tidak didapatkan perbedaan yang bermakna dari kedua kelompok perlakuan. Perubahan yang dapat dilihat adalah terjadinya peningkatan tekanan darah sistolik dan diastolik untuk setiap waktu setelah analgesia diberikan

Sacco menjelaskan bahwa terdapat suatu hubungan antara kejadian nyeri terhadap perubahan hemodinamik, dalam hal ini perubahan tekanan darah. Salah satu mekanisme yang disebabkan nyeri adalah disekresikannya substansi kimia berupa norepinefrin dan serotonin yang berfungsi sebagai opiat endogen dalam memodulasi nyeri. Substansi ini juga menstimulasi saraf simpatis sebagai baroreseptor yang meningkatkan tekanan darah. ${ }^{26,28-30}$

Efek analgesia (tramadol atau ketorolak) makin lama akan berkurang diikuti peningkatan nyeri pasca operasi. Hal ini menyebabkan terjadinya peningkatan tekanan darah sistolik dan diastolik secara berkala. Perubahan hemodinamik berupa peningkatan frekuensi denyut nadi dan nilai respirasi per menit pun tampak dalam data subjek penelitian ini dari saat analgesia diberikan (T0) hingga jam ke-8 (T8).

Skor VAS pada saat diberikan analgesia (T0) pada kedua kelompok menunjukkan angka 0. Hal ini disebabkan karena masih adanya efek anestesia dari bupivakain yang diberikan sebelumnya. Sensasi nyeri mulai dirasakan pada jam kedua (T2) setelah efek anestesia mulai hilang.

Sempat dilakukan penelitian-penelitian 
sebelumnya tentang perbandingan efek analgesia tramadol dan ketorolak. Ong dan Tan menyimpulkan bahwa ketorolak $30 \mathrm{mg}$ lebih efektif dari tramadol 50 mg. ${ }^{25}$ Lalu, Zackova membandingkan dengan dosis yang berbeda dimana dosis tramadol menjadi $100 \mathrm{mg}$, dan didapati tramadol lebih unggul. ${ }^{22}$ Dan Putland menemukan bahwa pemberian premedikasi tramadol 1,5 mg/kgBB IV lebih baik dari pada ketorolak $10 \mathrm{mg}$ IV dalam pencegahan nyeri. ${ }^{23}$ Sekarang, setelah dibandingkan antara tramadol 1,5 mg/kgBB IV dan ketorolak 30 mg IV ternyata tidak ditemukan perbedaan yang bermakna secara uji statistik.

Efektifitas tramadol dan ketorolak sebagai analgesia monoterapi tidaklah cukup untuk mengakomodir kebutuhan pasien akan tingkat nyeri pasca operatif yang rendah. Penelitian tentang kombinasi tramadol dan ketorolak sebagai analgesia multimodal pun telah dilakukan dan memberi hasil yang lebih baik dibanding sebagai monoterapi saja. ${ }^{31-33}$ Analgesia multimodal adalah suatu strategi terapi yang melakukan kombinasi akan pilihan analgesia yang ada dengan mekanisme kerja tiap agen yang berbeda, dengan tujuan berupa penanganan nyeri yang lebih baik dan efek samping lebih rendah. Keberadaan analgesia multimodal ini kini menjadi suatu hal yang harus diperhitungkan apabila kepuasan pasien pasca operasi ingin dicapai. ${ }^{34}$

Pemberian dosis sebuah obat bisa ditentukan oleh jumlah dosis tetap dari obat tersebut atau besar berat badan dari subjek penerimanya. ${ }^{35}$ Secara statistika, perlakuan terhadap dua kelompok penelitian harus diperlakukan sama semaksimal mungkin, termasuk jenis dosis yang diberikan (dosis tetap atau dosis berdasar berat badan). Dosis tramadol dan ketorolak yang diberikan dalam penelitian ini didasarkan pada penelitian sebelumnya yang Karakteristik berat badan, tinggi badan, dan IMT dari subjek tidak memberikan pengaruh bermakna sehingga pemberian dosis cara seperti ini bisa dilakukan, walaupun memang akan lebih baik bila digunakan dosis berdasarkan berat badan untuk kedua kelompok. Dan apabila ketorolak diberikan lebih dari dosis yang ditetapkan, tidak ada peningkatan efek obat melainkan hanya peningkatan efek samping saja. $^{36}$

\section{SIMPULAN}

Berdasarkan hasil penelitian maka didapatkan kesimpulan bahwa tramadol 1,5 $\mathrm{mg} / \mathrm{kgBB}$ IV ternyata memberikan efek yang sama dengan ketorolak $30 \mathrm{mg}$ IV terhadap tingkat nyeri pasca operasi seksio sesarea. Dengan demikian bisa dikatakan bahwa hipotesis nol $\left(\mathrm{H}_{0}\right)$ diterima dan hipotesis alternatif $\left(\mathrm{H}_{1}\right)$ ditolak.

\section{SARAN}

Ditemukan juga beberapa permasalahan yang belum terselesaikan selama proses penelitian, sehingga peneliti mengajukan beberapa saran, antara lain sebagai berikut :

1. Kurangnya subjek yang tersedia menjadi salah satu faktor yang mengurangi ketepatan dari penelitian ini. Disarankan bagi peneliti yang ingin meneliti topik ini selanjutnya untuk mengumpulkan subjek yang lebih banyak lagi.

2. Dalam penelitian ini tidak dilakukan kriteria inklusi dan eksklusi yang spesifik terhadap pengumpulan subjek, seperti rentang umur yang lebih kecil, riwayat kehamilan sebelumnya (jumlah kehamilan), dan lain sebagainya. Diharapkan untuk peneliti selanjutnya agar bisa menerapkan kriteria yang lebih spesifik lagi.

3. Dibutuhkan dedikasi dan komitmen yang tinggi dalam melakukan penelitian dengan prinsip observasi dalam kurun waktu tertentu. Disarankan untuk peneliti selanjutnya bisa membagi waktu yang baik dalam melaksanakannya.

4. Dibutuhkan penelitian lebih lanjut lagi 
mengenai perbandingan penggunaan analgesia yang membahas lebih detail lagi tentang lama kerja, resiko jangka panjang, dan dosis yang adekuat.

5. Bagi peneliti selanjutnya yang ingin membandingkan pengaruh dua atau lebih obat terhadap suatu hal, lebih baik bila menggunakan penggunaan dosis berdasarkan berat bedan dari subjek yang akan ditentukan.

\section{DAFTAR PUSTAKA}

1. Muhiman M, Thaib M Roesli, Sunatrio S, Dahlan R. Anestesiologi. Jakarta: Bagian Anestesiologi dan Terapi Intensif Fakultas Kedokteran Universitas Indonesisa; 2004.

2. Boulton TB, Blogg CE. Anestesiologi. Jakarta: EGC; 1994.

3. Harley I, Hore P. Anasthesia : an introduction. $\quad 5^{\text {th }}$ ed. IP Communications; 2012.

4. Sjamsuhidajat, de Jong. Buku ajar ilmu bedah. Edisi ke-3. Jakarta: EGC; 2010.

5. International Association for the Study of Pain. IASP Taxonomy. 2012 May 22 [cited 2014 Oct 11]. Available from: http://www.iasppain.org/Taxonomy?navItemNumber= 576

6. Owen H, Cousins MJ. Post-operative pain. Curr Anaesth Crit Care. 1990;2:25-31.

7. Saxena R. Bedside obstetrics and gynecology. JP Medical Ltd; 2014

8. Ramsay MAE. Acute postoperative pain management. Proc (Bayl Univ Med Cent). 2000;13:244-7.

9. Fogarty DJ, Carabine UA, Milligan KR. Comparison of the analgesic effects of intrathecal clonidine and intrathecal morphine after spinal anaesthesia in patients undergoing total hip replacement. $\mathrm{Br} \mathrm{J}$ Anaesth. 1993;71:661-4.

10. Matthes HWD, Maldonado R, Simonin F, Valverde O, Slowe S, Kitchen I, et al. Loss of morphine-induced analgesia , reward effect and withdrawal symptoms in mice lacking the $\mu$ opioid-receptor gene. Nature. 1996;383:819-23.

11. Hadi MRA, Kamaruljan HS, Saedah A, Nikabdullah. A Comparative study of intravenous patient-controlled analgesia morphine and tramadol in patients undergoing major operation. [Kubang Kerian]: Universiti Sains Malaysia; 2004.

12. Preston KL, Jasinski DR, Testa M. Abuse potential and pharmacological comparison of tramadol and morphine. Drug Alcohol Depend. 1991;27:7-17.

13. Vickers MD, O'Flaherty D, Szekely SM, Read M, Yoshizumi J. Tramadol: pain relief by an opioid without depression of respiration. Anaesthesia. 1992;47:291-96.

14. Scott LJ, Perry CM. Tramadol. Drugs. 2000;60:139-76.

15. Flacke JW, Bloor BC, Kripke BJ, Flacke WE, Warneck CM, Van Etten A, et al. Comparison of morphine, meperidine, fentanyl, and sulfentanyl in balanced anesthesia: a double-blind study. Anaesth Analg. 1985;64(9).

16. Singelyn FJ, Deyaert $M$, Joris $D$, Pendeville E, Gouverneur J. Effects of intravenous patient-controlled analgesia with morphine, continuous epidural analgesia, and continuos threein-one block on postoperative pain and knee rehabilitation after unilateral total knee arthroplasty. Anaesth Analg. 1998;87:88-92.

17. White PF. The role of non-opioid analgesic techniques in the management of pain after ambulatory surgery. Anaesth Analg. 2002;94:577-85.

18. Dahl V, Raeder JC. Non-opioid postoperative analgesia. Acta Anaesthesiol Scand. 2000;44:1191203.

19. Gunawan SG. Farmakologi dan terapi. Edisi ke-5. Jakarta: Badan Penerbit FKUI; 2012.

20. Handayani MKW. Pengaruh ketorolak intravena terhadap kadar kreatinin urin enam jam pasca bedah dengan anestesi umum. [Semarang]: Universitas Diponegoro; 2007.

21. Buckley MMT, Brogden RN. Ketorolac. Drugs. 1990;39:86-109.

22. Zackova $M$, Taddei $S$, Calò $P$, Bellochio A, Zanello M. Ketorolac vs tramadol in the treatment of postoperative pain during maxillofacial surgery. Minerva Anestiol. 2001;67:641-6. 
23. Putland AJ, McCluskey A. The analgesic efficacy of tramadol versus ketorolac in day-case laparascopic sterilization. Anaesthesia. 1999;54:382-5.

24. Rodriguez MJ, De La Torre MR, PerezIraola $P$, Fernandez-Cuervo $C$, Benitez P, Navarro A, et al. Comparative study of tramadol versus NSAIDS as intravenous continuous infusion for managing postoperative pain. Curr Ther Res. 1993;54:375-83.

25. Ong KS, Tan JML. Preoperative intravenous tramadol versus ketorolac for preventing postoperative pain after third molar surgery. Int $\mathrm{J}$ Oral Maxillofac Surg. 2004;33:274-8.

26. Dafny N. Chapter 6: Pain principles. [cited 2014 Oct 11]. Available from: http://neuroscience.uth.tmc.edu/s2/ chapter06.html

27. Post surgical pain. [cited 2014 Oct 12]. Available from: http://www.surgeryencyclopedia.c om/Pa-St/Post-Surgical-Pain.html

28. Weiner IB. Handbook of psychology, health psychology. New York: John Wiley \& Sons. 2003. p. 303.

29. Lippincott. Professional guide of pathophysiology. Philadelphia: Lippincott Williams \& Wilkins. 2010. h. 261.

30. Sacco M, Meschi M, Regolisti G, Detrenis S, Bianchi L, Bertorelli M, et al. The relationship between blood pressure and pain. J Clin Hypertens. 2013;15:600-5.
31. Pieri M, Meacci L, Santini L, Santini G, Dollorenzo R, Sansevero A. Control of acute pain after major abdominal surgery in 585 patients given tramadol and ketorolac by intravenous infusion. Eur Pubmed Cent. 2002;28:113-8.

32. Isiordia MA, Pozos AJ, Martinez R, Herrera JE, Perez J. Preemptive analgesic effectiveness of oral ketorolac plus local tramadol after impactes mandibular third molar surgery. Med Oral Patol Oral Cir Bucal. 2001;16:776-80.

33. Lopez FJ, Diaz I, Terron JA, Campos MD. Analysis of the analgesic interactions between ketorolac and tramadol during arthritic nociception in rat. 2004;484:157-65.

34. Chin ML. Multimodal analgesia: role of non opioid analgesics. American Society of Regional Anaesthesia and Pain Medicine. [cited on 2015 Jan 21] Available from https://www.asra.com/painresource/article/35/muktimodalanalgesia-role-of-non-opioid-analgesics

35. Pai MP. Drug dosing based on weight and body surface area: mathematical assumptions and limitations in obese adults. Pharmacotherapy. 2012;32:85668.

36. Drugs. Ketorolac injection. [cited 2015 Jan 27] Available from : http://www.drugs.com/pro/ketorolacinjection.html 